\title{
TYRP1 wt Allele
}

National Cancer Institute

\section{Source}

National Cancer Institute. TYRP1 wt Allele. NCI Thesaurus. Code C52252.

Human TYRP1 wild-type allele is located in the vicinity of 9p23 and is approximately $17 \mathrm{~kb}$ in length. This allele, which encodes 5,6-dihydroxyindole-2-carboxylic acid oxidase protein, is involved in the regulation of melanin biosynthesis. 